\title{
Pharmacognosy
}

\section{A chemophenetic study of the genus Maytenus s.l. (Celastraceae): contribution to the rational search of its bioactive metabolites}

\author{
Lorena Diniz Guimarães ${ }^{1,2}$, Fernanda Moreira do Amaral ${ }^{2,3}$, Natalia Barros dos Santos ${ }^{2}$, Ana Joffily ${ }^{2}$, \\ Maria Carolina Anholeti ${ }^{1,4,5}$ \& Selma Ribeiro de Paiva ${ }^{2}$
}

\begin{abstract}
Maytenus s.l. is a genus of the Celastraceae family and many of its species are used in traditional medicine. Most of the substances responsible for the biological activities of plants come from their secondary metabolism, such as terpenoids and flavonoids, which have multiple functions in the plant and can occur in a similar way in plant groups. Chemophenetics analyzes the occurrence of these substances in a taxon and can infer evolutionary trends and contribute to the rational search for new drugs. Chemosystematic parameters were used to analyze the data obtained through a bibliographic survey. The species of Maytenus s.l. were separated into three groups: species with accepted names, synonymous species with the genus Monteverdia and synonymous species with the genus Gymnosporia. Due to their great occurrence and structural variety in Maytenus s.l., triterpenes were chosen as chemosystematic markers, with friedelanes and quinone methide triterpenes being the most expressive types. Studies have already demonstrated the analgesic potential of quinone methides and the antitumor potential of phenolic triterpenes and dimers of these units. Together, the three classes assist in the circumscription of Maytenus s.s. and Monteverdia, while lupanes can be used in the separation of these genera. Oleanans are representative of Gymnosporia.

Key words: chemosystematics, chemotaxonomy, phytochemistry, plant chemophenetics, quinone-methides, triterpenes.

Resumo

Maytenus s.l. é um gênero da família Celastraceae e muitas de suas espécies são utilizadas na medicina tradicional. Grande parte das substâncias responsáveis pelas atividades biológicas das plantas provém do seu metabolismo secundário, como terpenoides e flavonoides, que desempenham múltiplas funções na planta e podem ocorrer de forma semelhante em grupos vegetais. A quimiofenética analisa a ocorrência dessas substâncias em um táxon e pode inferir sobre tendências evolutivas e contribuir na busca racional por novos fármacos. Foram utilizados parâmetros quimiossistemáticos para análise dos dados encontrados através de levantamento bibliográfico. As espécies de Maytenus s.l. foram separadas em três grupos: espécies com nomes aceitos, espécies sinonimizadas com o gênero Monteverdia e espécies sinonimizadas com o gênero Gymnosporia. Devido à sua grande ocorrência e variedade estrutural nas espécies de Maytenus s.l., os triterpenos foram escolhidos como marcadores quimiossistemáticos, sendo os triterpenos friedelanos e quinonametídeos os mais expressivos. Estudos já demonstraram o potencial analgésico de quinonametídeos e o potencial antitumoral de triterpenos fenólicos e dímeros dessas unidades. Juntas, as três classes auxiliam na circunscrição de Maytenus s.s. e Monteverdia, enquanto os lupanos podem ser utilizados na separação destes gêneros. Os oleananos são representativos em Gymnosporia.
\end{abstract}

Palavras-chave: quimiossistemática, quimiotaxonomia, fitoquímica, quimiofenética, quinonametídeos, triterpenos.

\footnotetext{
${ }^{1}$ Universidade Federal Fluminense, Faculdade de Farmácia, Depto. Farmácia e Administração Farmacêutica, R. Dr. Mario Vianna 523, Santa Rosa, 24241-002, Niterói, RJ, Brasil.

${ }^{2}$ Universidade Federal Fluminense, Inst. Biologia, Depto. Biologia Geral Setor de Botânica, Outeiro de São João Batista s/n, Centro, 24020-140, Niterói, RJ, Brasil.

${ }^{3}$ Universidade Federal do Rio de Janeiro, Museu Nacional, Prog. Pós-Graduação em Ciências Biológicas (Botânica), Quinta da Boa Vista s/n, São Cristóvão, 20940-040, Rio de Janeiro, RJ, Brasil.

${ }^{4}$ ORCID: <https://orcid.org/0000-0003-1552-9161>

${ }^{5}$ Author for correspondence: carolanholeti@gmail.com
} 


\section{Introduction}

One of the oldest forms of treatment and prevention of diseases is the use of medicinal plants. Even today, this practice is very widespread, especially in places where access to medicine is more difficult. In developed countries, the search for a healthier life based on nature has increased the consumption and use of plants as a therapeutic alternative (Petrovska 2012; Palhares et al. 2015). In Brazil, the government encourages this use through the National Policy of Medicinal Plants and Herbal Medicines ("Política e Programa Nacional de Plantas Medicinais e Fitoterápicos") approved by the Decree no 5.813, of 22 June 2006, which contributes to the development of methodologies and technologies for research and consequent increase in scientific knowledge on medicinal plants pharmacological properties (Brasil 2006).

Most of the bioactive substances in plants are derived from special (or secondary) metabolism. Genetic and environmental components influence the quantity and the quality of these metabolites, which act in the defense of the plant, in the attraction of pollinators and seed dispersers, as agents in plant-plant competition and in plantmicroorganism symbioses (Andrade \& Casali 1999). These multiple functions, typical of the special metabolites, are justified from the evolutionary point of view because when a characteristic can have multifunctionality, it is possible that it is maintained by natural selection (Wink 2003).

Plant systematics was initially based on morphological characters, with other parameters added over the years. Since special metabolites normally occur similarly in members of the same clade, their occurrence or absence may be indicative of the common origin, and hence of parentage (Wink 2003). Chemosystematics shows that chemistry and botany can be used in a complementary way in the study of plants. It is based on the existence of chemical gradients of affinity between plant groups and can be of great importance for the direction of phytochemical studies (Conde et al. 2010). In this field of science, plant chemophenetics recently arose as a new term to describe chemosystematic studies focused on exploiting the array of special metabolites in a given clade, contributing to the characterization of taxa, endorsement of established phylogenetic systems and the rational search for bioactive natural products (Zidorn 2019).
The genus Maytenus s.l. (including Gymnosporia) occurs in a wide variety of locations and many of its species are traditionally used for multiple medicinal purposes. In Brazil, the native species Monteverdia ilicifolia (Martius ex Reissek) Biral (accepted name of Maytenus ilicifolia Mart. ex Reiss.) (Biral et al. 2017) is popularly known as "espinheira-santa", and extensively used in the treatment of several diseases, especially gastritis and dyspepsia (Santos-Oliveira et al. 2009).

The genus Maytenus belongs to the family Celastraceae and was first described by Feullèe (1725), however, the first valid description for the genus was only published by Molina in 1782. Although providing a detailed description, the author attributed characteristics that do not correspond to the genus. The errors were recognized by Molina, in 1810, when the author updated the circumscription of Maytenus (Carvalho-Okano 1992). Due to this failure, the genus was recognized by other authors and mistakenly new names were attributed to this taxon, such as Haenkea by Ruiz and Pavon (1784), Celastrus by Willdenow (1798), Senacia by Lamarck (1817), Boaria by De Candolle (1844) and Tricerma, by Liebmann (1853). Maytenus s.l. includes about 150 species (McKenna et al. 2011). In Brazil there are 49 species and their center of diversity is the Atlantic Forest (Lombardi et al. 2015).

Regarded as a polyphyletic genus in the broadest sense, Maytenus was composed by three independent lineages, from Africa, Austral-Pacific and New World (Simmons et al. 2008). The first one was transferred to Gymnosporia, the second to Denhamia and the third incorporated Moya and Tricerma to redefine a new circumscription of the genus comprehending only species from the New World (McKenna et al. 2011). The paraphyly of the New World Maytenus was then determined by the position of a clade composed by Fraunhofera and Plenckia nested within it (Groppo et al. 2014). Recently, a new phylogenetic analysis conducted by Biral et al. (2017), based on molecular characters and fruit morphology using a large sampling of taxa, proposed the maintenance of Fraunhofera and Plenckia, the reestablishment of Tricerma and the segregation of the other two lineages into two genera: Maytenus, containing the type of the genus name, and Monteverdia.

In this scenario that includes several circumscriptions changes and considering that the morphological characteristics usually present a constant pattern within the genus, 
the chemophenetic study may be useful in the delimitation of the genus Maytenus s.l.. Also, in a group of species with diverse descriptions of medicinal use, the recognition of the distribution of its main chemical constituents can help to direct phytochemical research that leads to the isolation of its active constituents.

The objective of this study was to carry out a chemophenetic study of the genus Maytenus aiming to identify evolutionary trends and contribute to the rational search of their bioactive metabolites.

\section{Material and Methods}

Bibliographic survey

Using the keyword "Maytenus" in the online database "Science Direct", articles were collected from 1965 to 2016. Articles that did not address the isolation, identification or characterization of substances were excluded from the bibliographic survey.

\section{Election of chemical markers}

of the genus Maytenus s.l.

The data obtained from the bibliographic research were typed in the Microsoft Excel program, composing an organized database on the occurrence of chemical substances in Maytenus s.l. species. The chemosystematic markers were selected based on the occurrence and variety of chemical structures in the species studied (Santos et al. 2010).

\section{Chemosystematic parameters}

After obtaining data on the metabolic production of the genus Maytenus s.l., different chemical parameters were calculated, such as the number of occurrences (NO), the number of types (NT), the diversity index (DI) and the oxidation index (OI) (Santos et al. 2010).

\section{Results and Discussion}

Using the Science Direct database, 117 articles were found containing information about Maytenus species, regarding isolation or identification of chemical metabolites. The data were tabulated considering works published between 1965 and 2016. According to this database, only 43 species of Maytenus were investigated chemically until 2016.

A total of 307 substances were found during the bibliographic survey, which were chemically classified, and the number of occurrences (NO) of

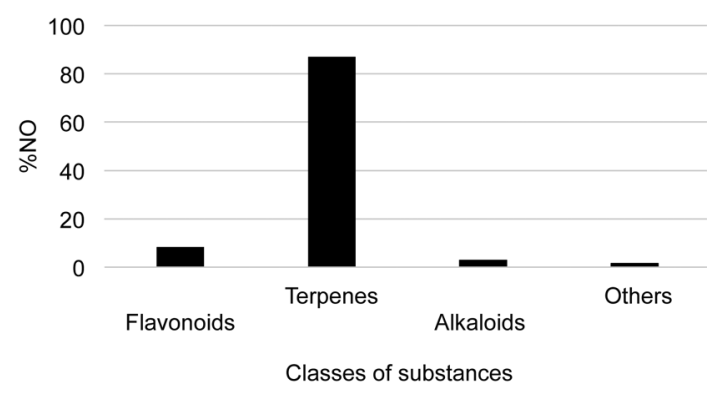

Figure 1 - Percentage of the number of occurrences ( $\%$ NO) for the classes of substances described in literature for Maytenus species.

each group of substances was calculated showing a greater relevance for the occurrence of terpenes $(\mathrm{NO}=417)$ within the genus Maytenus (Fig. 1).

The NO is a chemical parameter that indicates the degree of relevance of a particular class of substances to a taxon under study. The trend of production of a substance is observed by counting the number of times it is found in different species of the same taxon. The NO can also be expressed as a percentage $(\% \mathrm{NO})$.

After analysis 268 terpenes were identified, which were initially classified by the number of carbon atoms. The triterpenes showed the highest number of occurrences $(\mathrm{NO}=322)$, followed by the agarofuran sesquiterpenes $(\mathrm{NO}=89)$, characteristic of the Celastraceae family, and for which there are studies showing great biological potential with promising results in assays involving the evaluation of antitumor (Núñez et al. 2016), insecticide (González et al. 1993) and leishmanicidal activities (Delgado-Méndez et al. 2008). Figure 2 shows the distribution of terpenes in Maytenus based on the percentage of the number of occurrences.

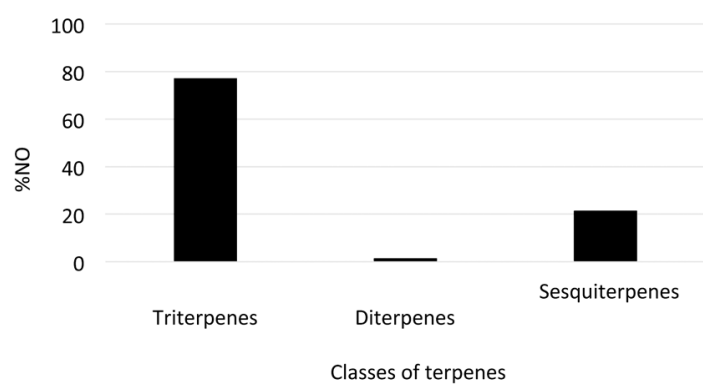

Figure 2 - Percentage of the number of occurrences $(\% \mathrm{NO})$ for groups of terpenes produced by species of Maytenus according to literature data. 
In addition to their vast occurrence, the triterpenes identified in Maytenus also showed a great structural variety and were chosen as chemosystematic markers of the genus. The amount of different structural types of a given chemical class for a particular taxon can be expressed as the number of types (NT). According to their structural features, 11 types of triterpenes $(\mathrm{NT}=$ 11) were found in Maytenus, the most expressive being friedelanes $(\mathrm{NO}=79)$ and quinone methides derivatives $(\mathrm{NO}=69)$ (Fig. 3).

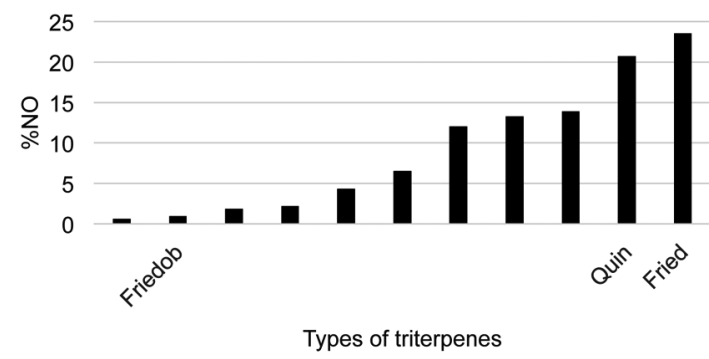

Figure 3 - Percentage of the number of occurrences (\% NO) for types of triterpenes found in species of Maytenus in literature. Hop = hopanes; Friedob = D:B friedobaccharanes; $\mathrm{Sec}=$ secofriedelanes; Urs = ursanes; Dam $=$ dammaranes; Ole $=$ oleananes; Phe $=$ phenolics; Lup $=$ lupanes; Dim $=$ dimers; Quin = quinone methides; Fri $=$ friedelanes.

The diversity index (DI) for the triterpenes identified in Maytenus was 85, a value considered high (Santos et al. 2010). It represents another way to express the distribution frequency of a given chemical class and is calculated based on the NO and the NT. From the evolutionary point of view, according to Borin \& Gottlieb (1993), the higher this index, the greater the probability of the taxon in question being a progenitor for other taxa, since it presents a great variety of structural types.

The compounds with the highest number of occurrences among the triterpenes were the quinone methides derivatives tingenone $(\mathrm{NO}=17)$ and pristimerin $(\mathrm{NO}=12)($ Fig. $4 \mathrm{a}-\mathrm{b})$. These substances have attracted much attention due to their potential as anticancer agents, as well as other quinone methides from Celastraceae species (Gomes et al. 2011; Rodrigues et al. 2019). Tingenone also demonstrated antimicrobial (Mena-Rejón et al. 2007) and peripheral antinociceptive effect (Veloso et al. 2017).
Friedelin was the friedelane triterpene with greater occurrence $(\mathrm{NO}=11)$ (Fig. $4 \mathrm{c})$. Studies demonstrated that this substance has several biological activities, such as antiulcerogenic (Mossi et al. 2004), antimicrobial (Kuete et al. 2007), anti-inflammatory, analgesic and antipyretic (Antonisamy et al. 2011), hypolipidemic (Duraipandiyan et al.2016) and cytotoxic potential (Subash-Babu et al. 2017). Besides its own biological properties, friedelin acts as a precursor of quinone methide triterpenes in Celastraceae. Corsino et al. (2000) demonstrated that friedelin is synthesized in the leaves of Monteverdia aquifolia (Mart.) Biral (Biral et al. 2017) and is transported to the roots where it is converted by oxidoreductases to tingenone and pristimerin (Souza-Moreira et al. 2016).

Phenolic triterpenes $(\mathrm{NO}=39)$ are also characteristic of the genus Maytenus and are formed from the reduction of quinone methides derivatives (Rodríguez et al. 2005). 6-oxotingenol $(\mathrm{NO}=4)($ Fig. $4 \mathrm{~d})$ is a representative of these substances and had demonstrated potential cytotoxicity against tumor cells (Shirota et al. 1994).

The species of Maytenus used for the chemophenetic study were divided into three groups, according to the classification of the Tropicos database (Tropicos.org 2019): species with accepted names, species that are synonymous of others of the Monteverdia genus proposed by Biral et al. (2017) and species synonymous of the genus Gymnosporia. The distribution of triterpene types was analyzed in these three groups, considering the number of occurrences (Fig. 5).
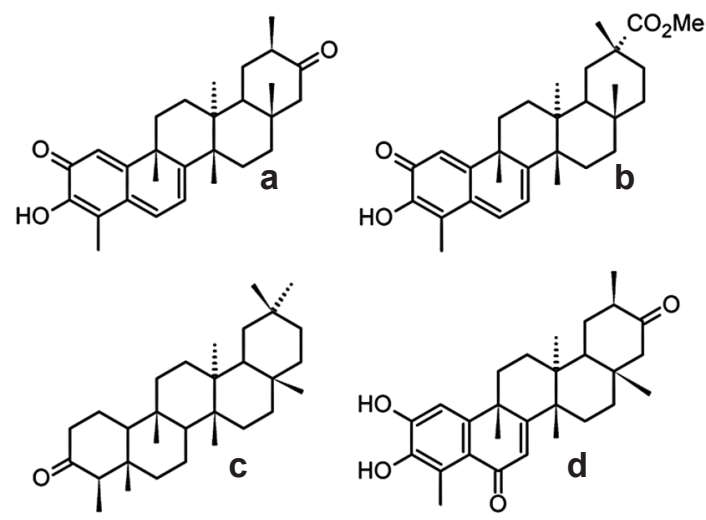

Figure 4 - a-d. Examples of triterpenes found in Maytenus species - a. tingenone; b. pristimerin; c. friedelin; d. 6-oxo-tingenol. 
Interpreting Figure 5 it is possible to observe that, in relation to the types of triterpenes, there is a greater similarity between the group of species with accepted names and those whose names were synonymized with Monteverdia. This is more evident if we consider phenolic triterpenes, dimers and quinone methides, which are restricted to these two groups. It is noteworthy that $85 \%$ of the dimers found are formed by units of quinone methide triterpenes bound to phenolic triterpenes, and the others by two units of phenolic triterpenes, which corroborates the importance of these skeletons in the circumscription of Maytenus and Monteverdia. The species synonymized with Gymnosporia are characterized by a greater occurrence of oleananes and friedelane triterpenes. The lupane triterpenes, on the other hand, may be useful in the separation between Maytenus and Monteverdia, since their occurrence is much more expressive in the second group.

The oxidation index (OI) shows the level of oxidation of a substance. It was calculated for all triterpenes identified in this study and the

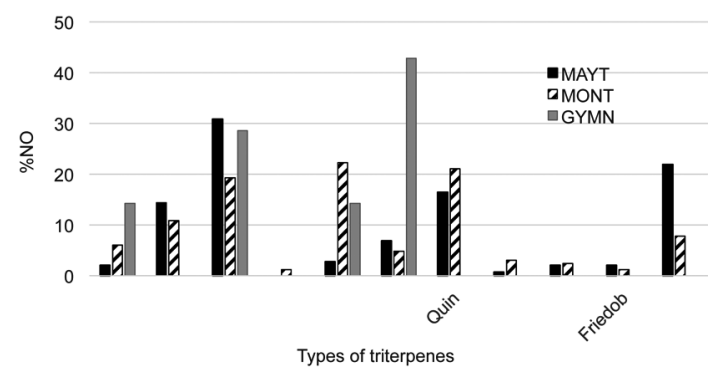

Figure 5 - Percentage of the number of occurrences of different types of triterpenes in three groups of Maytenus. MAYT $=$ species with accepted names; MONT = Monteverdia synonyms; GYMN = Gymnosporia synonyms; Dam = dammaranes; Phe = phenolics; Fri = friedelanes; Hop = hopanes; Lup = lupanes; Ole = oleananes; Quin = quinone methides; $\mathrm{Sec}=$ secofriedelanes; Urs $=$ ursanes; Friedob $=\mathrm{D}: \mathrm{B}$ friedobaccharanes; Dim = dimers. evolutionary index based on oxidation (EAo) was calculated for each group of triterpenes, showing that the triterpenes which represent a more derived characteristic in Maytenus are the quinone methides.

Oxidation reactions are evolutionarily important since the reactions that lead to most primary metabolites are mainly based on condensation and reduction and the pathways leading to the secondary metabolites, from these precursors, require oxidative steps. For this reason, most derived species are expected to produce substances with higher oxidation indexes than the basal ones (Gottlieb 1990).

By analyzing the evolutionary index concerning the oxidation in the three groups of plants, we find close values of EAo. However, when comparing the diversity indexes of triterpenes found in these groups, it is observed that the group of species with accepted names and the group of synonyms of the Monteverdia genus have a great diversity of triterpene structural types when compared to the group of species synonymized with Gymnosporia, characterizing a more derived character for this last group of species (Tab. 1).

\section{Conclusions}

The chemophenetic study of the genus Maytenus s.l. highlighted the occurrence of triterpenes, particularly triterpenes more oxidized such as the quinone methides, which drags much interest in terms of pharmacological potential. Due to its popular use in the treatment of gastric ulcers, the chemical studies in Brazil tend to focus on Monteverdia ilicifolia, but the chemophenetic analysis suggests the pharmacological potential of the genus as a whole and provides subsidies for new research with other species, reducing the overhead production in a single species.

The three groups of Maytenus s.l. presented different triterpene composition profiles. The

Table 1 - Diversity index (DI) and evolutionary index based on oxidation (EAo) for triterpenes from the three groups of Maytenus.

\begin{tabular}{cccc}
\hline $\begin{array}{c}\text { Chemosystematic } \\
\text { parameters }\end{array}$ & $\begin{array}{c}\text { Accepted names } \\
\text { for Maytenus }\end{array}$ & $\begin{array}{c}\text { Monteverdia } \\
\text { synonyms }\end{array}$ & $\begin{array}{c}\text { Gymnosporia } \\
\text { synonyms }\end{array}$ \\
\hline DI & 89 & 83 & 38,5 \\
EAo & $-1,17$ & $-1,24$ & $-1,03$ \\
\hline
\end{tabular}


occurrence of quinone methides, phenolic derivatives and dimers of these triterpene units can assist in the circumscription of Maytenus s.s. and Monteverdia, while lupanes may be used in the separation of these groups, since its occurrence is more representative in Monteverdia. The oleananes are more representative in Gymnosporia. A difference was also observed regarding the diversity index of triterpenes, which was much lower in Gymnosporia than in the other two groups.

\section{Acknowledgements}

The authors are grateful to FAPERJ for fellowships (process numbers E-26/201,159/2016 and E-26/200,232/2017).

\section{References}

Andrade FMC \& Casali VWD (1999) Plantas medicinais e aromáticas: relação com o ambiente, colheita e metabolismo secundário. Arte Livros, Viçosa. 139p.

Antonisamy P, Duraipandiyan V \& Ignacimuthu S (2011) Anti-inflammatory, analgesic and antipyretic effects of friedelin isolated from Azima tetracantha Lam. in mouse and rat models. Journal of Pharmacy and Pharmacology 63: 1070-1077.

Biral L, Simmons MP, Smidt EC, Tembrock LR, Bolson M, Archer RH \& Lombardi JA (2017) Systematics of New World Maytenus (Celastraceae) and a new delimitation of the genus. Systematic Botany 42 : $1-14$.

Borin MRMB \& Gottlieb OR (1993) Steroids, taxonomic markers? Plant Systematics and Evolution 184: 41-76.

Brasil (2006) Política e Programa Nacional de Plantas Medicinais e Fitoterápicos. Decreto $n^{\circ} 5.813$, de 22 de junho de 2006. Available at <https://www. planalto.gov.br/ccivil_03/_Ato2004-2006/2006/ Decreto/D5813.htm>. Access on 24 May 2019.

Carvalho-Okano RM (1992) Estudos taxonômicos do gênero Maytenus MOL. emend. MOL. (Celastraceae) do Brasil Extra-Amazônico. Tese de Doutorado. Universidade Estadual de Campinas, Campinas. 253p.

Conde MMS, Somner GV \& Germano Filho P (2010) Os sistemas de classificação. In: Kaplan MAC, Abreu HS, Lima HRP \& Soares GLG (eds.) Abordagem quimiossistemática e evolução química de fanerógamas. Ed. Edur UFRRJ, Seropédica. Pp. 17-37.

Corsino J, Carvalho PRF, Kato MJ, Latorre LR, Oliveira OMMa, Araújo AR, Bolzani VS, França SC, Pereira MAS \& Furlan M (2000) Biosynthesis of friedelane and quinonemethide triterpenoids is compartmentalized in Maytenus aquifolium and Salacia campestres. Phytochemistry 55: 741-748.
Delgado-Méndez P, Herrera N, Chávez H, EstévezBraun A, Ravelo AG, Cortes F, Castanys S \& Gamarro F (2008) New terpenoids from Maytenus apurimacensis as MDR reversal agents in the parasite Leishmania. Bioorganic e Medicinal Chemistry 16: 1425-1430.

Duraipandiyan V, Al-Dhabi NA, Irudayaraj SS \& Sunil C (2016) Hypolipidemic activity of friedelin isolated from Azima tetracantha in hyperlipidemic rats. Brazilian Journal of Pharmacognosy 26: 89-93.

Gomes JPM, Cardoso CRP, Varanda EA, Molina JM, Fernandez MF, Olea N, Carlos IZ \& Vilegas W (2011) Antitumoral, mutagenic and (anti)estrogenic activities of tingenone and pristimerin. Brazilian Journal of Pharmacognosy 21: 963-971.

González AG, Jiménez IA, Ravelo AG \& Bazzocch IL (1993) Minor sesquiterpenes from Maytenus canariensis with insecticidal and antifeedant activity. Tetrahedron 49: 6637-6634.

Gottlieb OR (1990) Phytochemicals: differentiation and function. Phytochemistry 29: 1715-1724.

Groppo M, Simmons MP, Cappa JJ, Biral L \& Lombardi JA(2014) A new species of Maytenus (Celastraceae) with fleshy fruits from eastern Brazil, with notes on the delimitation of Maytenus. Systematic Botany 39: 478-484.

Kuete V, Nguemeving JR, Beng VP, Azebaze AG, Etoa FX, Meyer M, Bodo B \& Nkengfack AE (2007) Antimicrobial activity of the methanolic extracts and compounds from Vismia laurentii De Wild (Guttiferae). Journal of Ethnopharmacology 109: 372-379.

Lombardi JA, Groppo M \& Biral L (2015) Celastraceae. In: Lista de espécies da flora do Brasil. Jardim Botânico do Rio de Janeiro. Available at $<$ http://floradobrasil. jbrj.gov.br/jabot/floradobrasil/FB6746>.

McKenna MJ, Simmons MP, Bacon CD \& Lombardi JA (2011) Delimitation of the segregate genera of Maytenus s.l. (Celastraceae) based on morphological and molecular characters. Systematic Botany 36: 922-932.

Mena-Rejón GJ, Pérez-Espadas AR, Moo-Puc RE, Cedillo-Rivera R, Bazzocchi IL, Jiménez-Diaz IA \& Quijano L (2007) Antigiardial activity of triterpenoids from root bark of Hippocratea excelsa. Journal of Natural Products 70: 863-865.

Mossi AJ, Cansian RL, Carvalho AZ, Dariva C, Oliveira JV, Mazutti M, Filho IN \& Echeverrigaray S (2004) Extraction and characterization of volatile compounds in Maytenus ilicifolia, using highpressure CO2. Fitoterapia 75: 168-178.

Núñez MJ, Jiménez IA, Mendoza CR, Chavez-Sifontes M, Martinez ML, Ichiishi E, Tokuda R, Tokuda H \& Bazzocchi IL (2016) Dihydro- $\beta$-agarofuran sesquiterpenes from Celastraceae species as anti-tumour-promoting agents: structure-activity relationship. European Journal of Medicinal Chemistry 111: 95-102. 
Palhares RM, Drummond MG, Brasil BSAF, Cosenza GP, Brandão MGL, Oliveira G (2015) Medicinal plants recommended by the world health organization: DNA barcode identification associated with chemical analyses guarantees their quality. PLoS One 10: e0127866.

Petrovska BB (2012) Historical review of medicinal plants' usage. Pharmacognosy Reviews 6: 1-5.

Rodrigues ACBC, Oliveira FP, Dias RB, Sales CBS, Rocha CAG, Soares MBP, Costa EV, Costa EV, Silva FMA, Rocha WC, Koolenf HHF \& Bezerra (2019) In vitro and in vivo anti-leukemia activity of the stem bark of Salacia impressifolia (Miers) A.C. Smith (Celastraceae). Journal of Ethnopharmacology 231: 516-524.

Rodríguez FM, López MR, Jiménez IA, Moujir L, Ravelo AG \& Bazzocchi IL (2005) New phenolic triterpenes from Maytenus blepharodes. Semisynthesis of 6-deoxoblepharodol from pristimerin. Tetrahedron 61: 2513-2519.

Santos MIS, Lima HRP \& Kaplan MAC (2010) Metodologia em quimiossistemática. In: Kaplan MAC, Abreu HS, Lima HRP \& Soares GLG (eds.) Abordagem quimiossistemática e evolução química de fanerógamas. Ed. Edur UFRRJ, Seropédica. Pp. 39-49.

Santos-Oliveira R, Coulaud-Cunha S \& Colaço W (2009) Revisão da Maytenus ilicifolia Mart. ex Reissek, Celastraceae. Contribuição ao estudo das propriedades farmacológicas. Revista Brasileira de Farmacognosia 19: 650-659.

Shirota O, Moritak H, Akjxa O \& Itokawa H (1994) Cytotoxic aromatic triterpenes from Maytenus ilicifolia and Maytenus chuchuhuasca. Journal of natural products 57: 1675-1681.
Simmons MP, Cappa JJ, Archer RH, Ford AJ, Eichstedt D \& Clevinger CC (2008) Phylogeny of the Celastreae (Celastraceae) and the relationships of Catha edulis (qat) inferred from morphological characters and nuclear and plastid genes. Molecular Phylogenetics and Evolution 48: 745-757.

Souza-Moreira TM, Alves TB, Pinheiro KA, Felippe LG, Lima GMA, Watanabe TF, Barbosa CC, Santos VAFFM, Lopes NP, Valentini SR, Guido RVC, Furlan M \& Zanelli CF (2016) Friedelin synthase from Maytenus ilicifolia: Leucine 482 plays an essential role in the production of the most rearranged pentacyclic triterpene. Scientific Reports. Available at <https:/www.ncbi.nlm.nih.gov/pmc/articles/ PMC5118845/>. Access on 18 June 2019. DOI: $10.1038 /$ srep36858

Subash-Babu P, Li DK \& Alshatwi AA (2017) In vitro cytotoxic potential of friedelin in human MCF-7 breast cancer cell: regulate early expression of Cdkn2a and pRb1, neutralize mdm2-p53 amalgamation and functional stabilization of p53. Experimental and Toxicologic Pathology 69: 630-636.

Veloso CC, Soares GL, Perez AC, Rodrigues VG \& Silva FC (2017) Pharmacological potential of Maytenus species and isolated constituents, especially tingenone, for treatment of painful inflammatory diseases. Brazilian Journal of Pharmacognosy 27: 533-540.

Wink M (2003) Evolution of secondary metabolites from an ecological and molecular phylogenetic perspective. Phytochemistry 64: 3-19.

Zidorn C (2019) Plant chemophenetics - a new term for plant chemosystematics / plant chemotaxonomy in the macro-molecular era. Phytochemistry 163: 147-148. 